\title{
Effect of Quinoid Mediators on the Decolorization of Azo Dyes by the Strain CD-2
}

\author{
Da Shen, Dongjin Leng, Cong Li, Congrong Wu, Daizong Cui* \\ College of Life Science, Northeast Forestry University, Harbin, China \\ Email: *siyu19831114@163.com
}

How to cite this paper: Shen, D., Leng, D.J., Li, C., Wu, C.R. and Cui, D.Z. (2016) Effect of Quinoid Mediators on the Decolorization of Azo Dyes by the Strain CD-2. Advances in Chemical Engineering and Science, 6, 335-344.

http://dx.doi.org/10.4236/aces.2016.64034

Received: June 15, 2016

Accepted: August 23, 2016

Published: August 26, 2016

Copyright $\odot 2016$ by authors and Scientific Research Publishing Inc. This work is licensed under the Creative Commons Attribution International License (CC BY 4.0).

http://creativecommons.org/licenses/by/4.0/

\begin{abstract}
In the present study, the effects of various quinone compounds on the decolorization rates of azo dyes by the $E$. coli strain CD-2 were investigated. The results showed that Lawsone was the most effective redox mediator. The optimum concentration for Lawsone is $0.1 \mathrm{mmol} / \mathrm{L}$. The effects of physic-chemical parameters on the Methyl Orange degradation by the strain were determined. The results indicated that, in the quinone mediated decolorization system, strain CD-2 exhibited a good degradation ability in the range of $\mathrm{pH}$ from 4 to 9 , temperature from $20^{\circ} \mathrm{C}$ to $50^{\circ} \mathrm{C}$ and salinity from $1 \%$ to $6 \%$. With Lawsone as a redox mediator, a broad spectrum of azo dyes with different structures could be decolorized by the strain. All the results showed that the addition of a redox mediator can be valuable for treating dye-colored wastewaters.
\end{abstract}

\section{Keywords}

Azo Dyes, Anaerobic Decolorization, Anthraquinone Mediator

\section{Introduction}

Azo dyes, which characterized by one or more azo bonds, have been widely used in textile, food, cosmetics, paper printing and other industries [1] [2]. However, during production and application, about ten percent to fifteen percent untreated dyes discharge into environments with industrial effluents [3]. The characters of azo dye wastewater are high chroma, high concentration organics and high complicated components. Some azo dyes and their intermediate metabolites may cause cancer, malformation and mutation which seriously endanger the health of humans and animals [4]. Therefore, the different technologies have been developed for the effective treatment of azo dyes before emission. 
Many techniques such as physical, chemical and biological processes are used to treat azo dyes. In particular, biological processes have received more interests due to their cost effective, lower sludge production and lower energy consumption [5]. It had been reported that many bacteria had the ability of decolorizing azo dyes under anaerobic conditions such as Clostridium, Eubacterium, Escherichia and Bacillus [6]-[9]. However, the bio-decolorization of azo dyes by bacteria often has problems such as slow decolorization rate and substrate limitation, which seriously hinder the industrial application of anaerobic biological decolorization of azo dyes [10].

Recently, many studies indicated that anthraquinone compounds (such as anthraquinone-2,6-disulfonate (AQDS), 2-anthraquinonesulfonate (AQS) and Lawsone) enhance the anaerobic decolorization of the azo dyes. Anthraquinone compounds can improve the decolorization efficiency of azo dyes by enhancing the electron transfer and avoid the sterichindrance of the dye molecules as redox mediators [11] [12]. In the azo dye decolorization system mediated by anthraquinone, bacteria are capable of utilizing different electron donors to promote reductive decolorization of azo dyes.

Therefore, we focus on the bacterial decolorization and degradation of azo dyes catalyzed by redox mediators and the further investigation to enhance the applicability of redox mediators on the bio-transformation of azo dyes.

\section{Materials and Methods}

\subsection{Chemicals}

The five azo dyes used in the experiments (Methyl Orange, Congo Red, Methyl Red, Eriochrome RedBand Ponceau S) were all procured from the Guangfu Fine Chemical Research Institute (Tianjin, China) and the four anthraquinone mediator (Lawsone, AQDS, Menadione and Bromamine Acid) were obtained from Sigma-Aldrich (St. Louis, Missouri, USA). Methyl Orange was a sulfonatedazo dye and was selected as a model compound in this study. Some properties of the azo dyes and quinones used in this study were summarized in Table 1 .

\subsection{Bacterial Strain and Culture Medium}

The E. coli strain CD-2 which had a high ability to decolorize azo dyes under anaerobic conditions was isolated by us from a wastewater treatment plant in Liaoning province. The degradation medium used in this study contained the following: $10 \mathrm{~g} \cdot \mathrm{L}^{-1}$ glucose, $10 \mathrm{~g} \cdot \mathrm{L}^{-1} \mathrm{NH}_{4} \mathrm{Cl}, 10 \mathrm{~g} \cdot \mathrm{L}^{-1} \mathrm{KH}_{2} \mathrm{PO}_{4}, 10 \mathrm{~g} \cdot \mathrm{L}^{-1} \mathrm{Na}_{2} \mathrm{HPO}_{4}$ and $10 \mathrm{~g} \cdot \mathrm{L}^{-1} \mathrm{MgSO}_{4}$.

\subsection{Effect of Different Mediators on Anaerobic Decolorization of Azo Dyes}

Strain CD-2 was grown aerobically at $37^{\circ} \mathrm{C}, 160 \mathrm{r} / \mathrm{min}$ until the $\mathrm{OD}_{600}$ reached to 1.6 in the degradation medium. Bacterial cells were harvested by centrifugation $(7000 \mathrm{r} / \mathrm{min}$, $10 \mathrm{~min}$ ). Cells were washed twice with $20 \mathrm{mmol} / \mathrm{L}$ phosphate buffer ( $\mathrm{pH}$ 7.0) and suspended in $50 \mathrm{ml}$ phosphate buffer. Then the cells were transferred to serum bottles. Oxygen was removed by repeated evacuation and flushing with nitrogen gas. 0.1 
Table 1. Chemical structure of redox mediators and azo dyes used in this study.

\begin{tabular}{|c|c|c|c|}
\hline Name & Chemical structure & $\lambda_{\max }$ & Solubility \\
\hline Menadione & & 230 & Water soluble \\
\hline Lawsone & & 267 & Water soluble \\
\hline AQDS & & 450 & Water soluble \\
\hline $\begin{array}{c}\text { Bromoamine } \\
\text { Acid }\end{array}$ & & 492 & Water soluble \\
\hline $\begin{array}{l}\text { Methyl } \\
\text { Orange }\end{array}$ & & 464 & Water soluble \\
\hline Methyl Red & & 430 & Alcohol soluble \\
\hline Ponceau S & & 515 & Water soluble \\
\hline Gongo Red & & 500 & Water soluble \\
\hline $\begin{array}{c}\text { Eriochrome } \\
\text { Red B }\end{array}$ & & 474 & Water soluble \\
\hline
\end{tabular}


$\mathrm{mmol} / \mathrm{L}$ of Lawsone, AQDS, Bromamine Acid and Menadione were added to the anaerobic system, respectively. The final dye concentration was $0.1 \mathrm{mmol} / \mathrm{L}$. The samples were taken at different time interval and analyzed for dye decolorization. All measurements were taken in triplicate.

\subsection{Effect of Mediators Concentration on Anaerobic Decolorization of Azo Dyes}

The strain CD-2 was inoculated under aerobic condition in the degradation medium until the $\mathrm{OD}_{600}$ reached to 1.6. Cells washed twice with phosphate buffer and suspended in $50 \mathrm{ml}$ serum bottles. Methyl orange was added to the degradation system to achieve a dye concentration of $0.1 \mathrm{mmol} / \mathrm{L}$. Lawsone was added to the system as a redox mediator, and the concentration of the Lawsone was $0.05 \mathrm{mmol} / \mathrm{L}, 0.1 \mathrm{mmol} / \mathrm{L}, 0.15 \mathrm{mmol} / \mathrm{L}$, $0.2 \mathrm{mmol} / \mathrm{L}$ and $0.25 \mathrm{mmol} / \mathrm{L}$, respectively. Anaerobic bottles were incubated in $37^{\circ} \mathrm{C}$. The samples were taken at different time intervals and analyzed for dye degradation. All measurements were taken in triplicate.

\subsection{Effect of Physical and Chemical Factors on the Decolorization Rate of Azo Dyes}

The strain $\mathrm{CD}-2$ was inoculated under aerobic condition until the $\mathrm{OD}_{600}$ reached to 1.6. Cells were washed twice with phosphate buffer and suspended in $50 \mathrm{ml}$ anaerobic bottle. Methyl orange was added to the degradation system to achieve a dye concentration of $0.1 \mathrm{mmol} / \mathrm{L}$. $0.1 \mathrm{mmol} / \mathrm{L}$ of Lawsone was added to the decolorization system as an anaerobic redox mediator. The degradation system was incubated under different physical and chemical conditions.

Effects of $\mathrm{pH}$ : The reaction mixtures were adjusted to $\mathrm{pH}$ values between 4 to 9 by using $1 \mathrm{~mol} / \mathrm{L} \mathrm{HCl}$ and $\mathrm{NaOH}$.

Effects of temperature: The cultures were incubated at various temperatures $\left(20^{\circ} \mathrm{C}\right.$ $\left.50^{\circ} \mathrm{C}\right)$.

Effects of salinity: Various concentrations $(1 \%-6 \%)$ of $\mathrm{NaCl}$ were added to the media.

\subsection{Effect of Mediators on Different Azo Dyes Decolorization}

The strain CD-2 was inoculated under aerobic condition until the $\mathrm{OD}_{600}$ reached to 1.6. Cells were washed twice with phosphate buffer and suspended in $50 \mathrm{ml}$ anaerobic bottle. Methyl Red, Congo red, Eriochrome Red B, Ponceau S were added to the degradation system to achieve a dye concentration of $0.1 \mathrm{mmol} / \mathrm{L}$. Lawsone was added to the reaction system as a mediator. The reaction system was placed in anaerobic culture of $37^{\circ} \mathrm{C}$, and the decolorization efficiency of azo dyes was observed. All measurements were taken in triplicate.

\section{Results and Discussion}

\subsection{Effect of Different Anthraquinone on the Anaerobic Decolorization of Methyl Orange by Strain CD-2}

Strain CD-2 was tested for its ability to decolorize Methyl Orange under anaerobic 
conditions with different anthraquinone. As shown in Figure 1, after 6 h of incubation, only $30 \%$ of the Methyl orange was decolorized without the addition of a redox mediator. However, in the presence of Bromamine Acid and AQDS, over $40 \%$ and $60 \%$ of the dye was decolorized in $6 \mathrm{~h}$. In the presence of Menadione, over $90 \%$ of the dye was decolorized in $6 \mathrm{~h}$ (with a specific decolorization rate of $3.15 \mathrm{mg} / \mathrm{g}$ cell/h). Strain CD-2 decolorized $85 \%$ of the Methyl Orange in $3 \mathrm{~h}$ when the dye decolorizing mixture contained Lawsone (with a specific decolorization rate of $8.84 \mathrm{mg} / \mathrm{g}$ cell/h). The results demonstrated that the addition of quinoid redox mediators significantly increased the rate of decolorization of Methyl Orange under anaerobic conditions, and compared with other mediators, Lawsone was a more effective mediator.

The effects of different redox mediators varied significantly among different decolorization system. Previous studies demonstrated that the addition of AQDS to E. coli resulted in much higher azo dye decolorization rate under anaerobic conditions. Kudlich et al. reported that, for the strain Sphingomonas xenophaga BN6, the addition of AQDS on the dye reduction system allowed higher decolorization than other mediators [13]. In this study, Lawsone was the most effective mediator. In the presence of Lawsone, the decolorization rate of Methyl Orange increased about 8.5 times.

\subsection{Effect of Concentrations of Anthraquinone Mediator on Decolorization of Methyl Orange by Strain CD-2}

Previous studies demonstrated that the decolorization rate of the dye is related to the

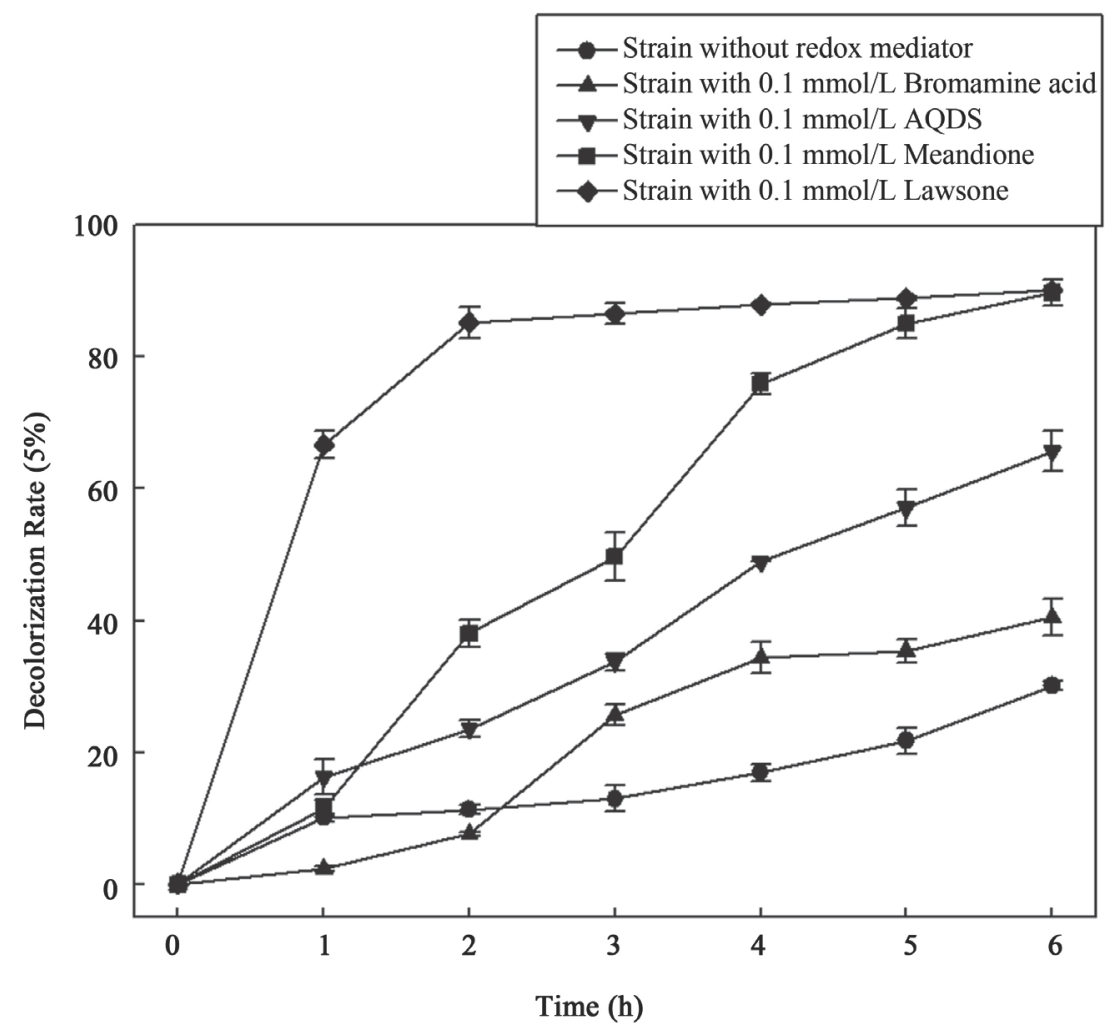

Figure 1. The decolorization rate of Methyl Orange by different mediators. 
concentration of the anthraquinone mediator [14]. In this study, the effects of different concentrations of the mediator on the decolorization of azo dyes were determined (Figure 2). As shown in Figure 2, different concentrations of Lawsone added to the system can increase the decolorization rate of the dye. The maximum decolorizing rate was observed when the concentration was $0.1 \mathrm{mmol} / \mathrm{L}$, and about $95 \%$ Methyl Orange was degraded within $3 \mathrm{~h}$. (With a specific decolorization rate of $6.87 \mathrm{mg} / \mathrm{g}$ cell/h.)

The further increase of the Lawsone concentration over $0.1 \mathrm{mmol} / \mathrm{L}$, the stimulating effect on decolorization decreased correspondingly. When the decolorization system contained $0.25 \mathrm{mmol} / \mathrm{L}$ Lawsone, only about $76 \%$ dye was degraded within $3 \mathrm{~h}$ (with a specific decolorization rate of $5.23 \mathrm{mg} / \mathrm{g}$ cell/h).These results indicate that $0.1 \mathrm{mmol} / \mathrm{L}$ of mediator was suitable for dye decolorization.

The degradation rate of azo dyes should be increased with the concentration of the mediator raised in the low range. However, when the concentration increases to a certain degree, the decolorization efficiency of azo dyes was no longer increased or even decreased. This might be attributed to the lack of electron donors, which limited the reduction rate of anthraquinone mediator. In addition, high concentrations of anthraquinone compounds may inhibit the growth of cells.

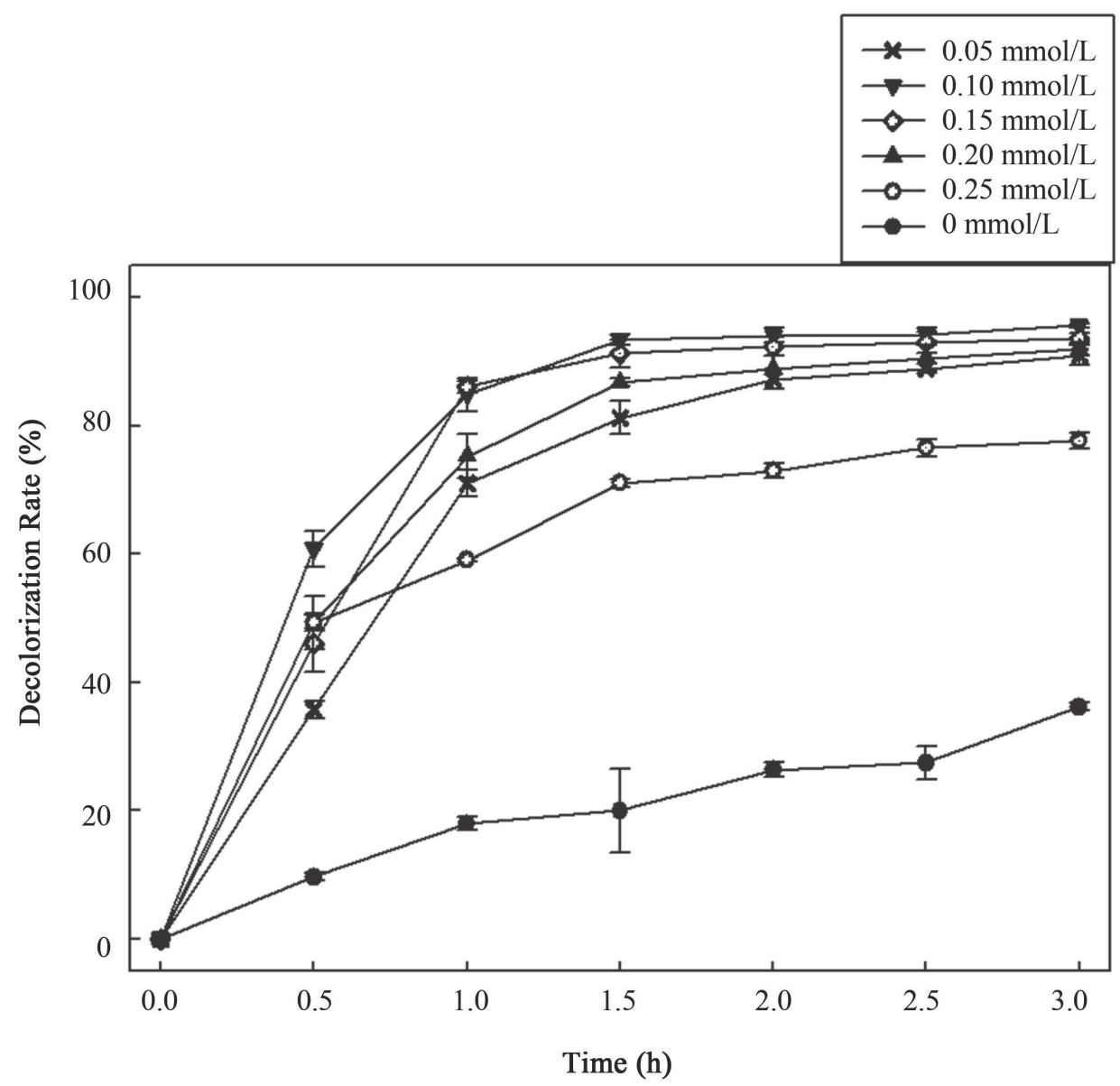

Figure 2. The decolorization rate of the dye by different concentrations of Lawsone. 


\subsection{The Effect of Physical and Chemical Factors on the Decolorization of Azo Dyes}

\subsubsection{Effect of pH on Decolorization of Azo Dyes}

The decolorizing rate of azo dye in different $\mathrm{pH}$ was studied by us, and the result was shown in Figure 3(a). It showed that decolorization of the dye could be observed in a wide range of $\mathrm{pH}$ from $4-9$ by the strain $\mathrm{CD}-2$. The maximum decolorization rate was observed when the culture's $\mathrm{pH}$ was 7 , and about $92 \%$ Methyl Orange was degraded after $3.5 \mathrm{~h}$ (with a decolorization rate of $5.24 \mathrm{mg} / \mathrm{g}$ cell/h). Both the high $\mathrm{pH}$ and low $\mathrm{PH}$ influence the decolourization rate of the azo dye. When the culture's $\mathrm{pH}$ was 9 , only about 37\% Methyl Orange was degraded after $3.5 \mathrm{~h}$ incubation (with a decolorization rate of $2.13 \mathrm{mg} / \mathrm{g}$ cell $/ \mathrm{h}$ ). When the culture's $\mathrm{pH}$ was 5 , the lowest as $17 \%$ Methyl Orange was degraded after $3.5 \mathrm{~h}$ (with a decolorization rate of $1.01 \mathrm{mg} / \mathrm{g}$ cell/ $\mathrm{h}$ ).

\subsubsection{Effect of Temperature on Decolorization of Azo Dyes}

In this study, the temperature range of $20^{\circ} \mathrm{C}-50^{\circ} \mathrm{C}$ was arranged for the dye decolorizing tests (Figure $3(\mathrm{~b})$ ). The optimum temperature for the dye decolorization was $37^{\circ} \mathrm{C}$, at which over $99 \%$ of Methyl Orange was degraded within $2 \mathrm{~h}$ (with a decolorization rate of $10.8 \mathrm{mg} / \mathrm{g}$ cell/ $/ \mathrm{h}$ ). The degradation rate decreased greatly when the temperature declined. Only $38 \%$ of Methyl orange was decolorized when the temperature dropped to $20^{\circ} \mathrm{C}$. However, the decolorized rate remained above $62 \%$ at $50^{\circ} \mathrm{C}$.

The decolorization rate of azo dyes will be gradually strengthened with the increase of the temperature in a certain range. This is because the higher temperature would provide the higher energy for the dye molecules to break down. However, in the system of biological catalysis decolorization, negative effect will be brought to influence the growth and enzyme activity of the cells at a high temperature. In this study, with the gradual increase of temperature, the degradation rate of azo dyes is reflected in the trend of first increasing and then decreasing. Similar results have been reported, such as Dos Santos et al. found that the decolorization rate of azo dye Reactive Red 2 was increased about 2.5 times compared with the $30^{\circ} \mathrm{C}$ in the anaerobic decolorization system mediated by AQS [15].

\subsubsection{Effect of Salinity on Decolorization of Azo Dyes}

In this study, the effects of salinity on the degradation rate of azo dye were measured

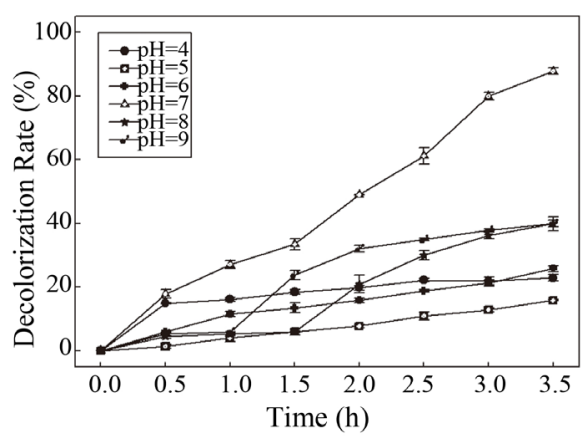

(a)

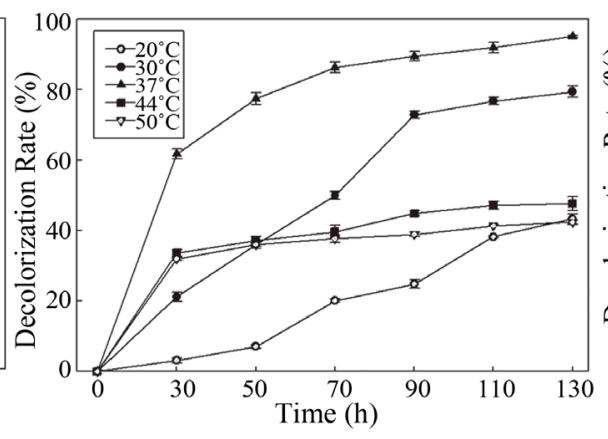

(b)

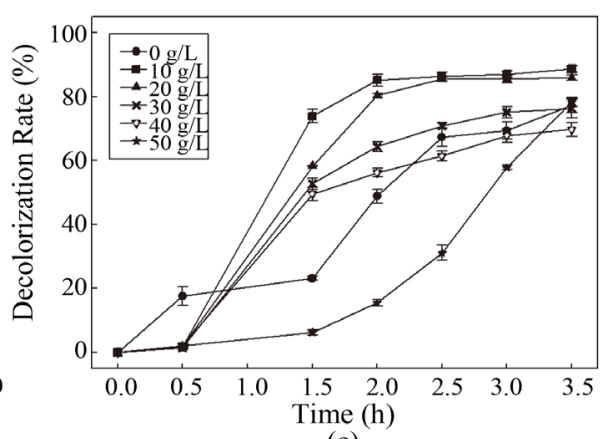

(c)

Figure 3. The effects of physical and chemical factors on the decolorization of azo dyes. 
(Figure 3(c)). It was observed that salinity is not the main limitation factor for the degradation of Methyl Orange. About $72 \%$ of the dye was degraded within $3.5 \mathrm{~h}$ in the exist of $10 \mathrm{~g} / \mathrm{L} \mathrm{NaCl}$, (with a decolorization rate of $4.3 \mathrm{mg} / \mathrm{g}$ cell/h). The strain could grow quite well at high salt concentration. Even the concentration of $\mathrm{NaCl}$ was $60 \mathrm{~g} / \mathrm{L}$, $70 \%$ of Methyl Orange could still be degraded within $3.5 \mathrm{~h}$.

\subsection{Decolourization of Different Azo Dyes by Strain CD-2}

The results suggested that the addition of Lawsone increased the decolorization rates of all tested azo dyes (Table 2). Without a redox mediator, the strain CD-2 could barely decolorize Ponceau S. However, over $82 \%$ of the dye was decolorized when the system contained $0.1 \mathrm{mmol} / \mathrm{L}$ Lawsone, the specific decolorization rate was $6.59 \mathrm{mg} / \mathrm{g}$ cell/h. Similarly, for Gongo Red, when the strain CD-2 was incubated with quinoid compound, the specific decolorization rate increased 2.12 times, from 3.84 to $8.15 \mathrm{mg} / \mathrm{g}$ cell/h. When the decolorization system contained Lawsone, the decolorization rate of both Methyl Red and Eriochrome Red B showed 1.30 to 2.06 fold increases, and the specific decolorization rates were 2.30 and $2.97 \mathrm{mg} / \mathrm{g}$ cell/h, respectively.

It had been reported that the different efficiencies of various azo dyes decolorization are greatly due to the chemical structures of the azo dyes. The dyes with simple structures and low molecular weights are decolorized faster than those with complex structures. This is likely because the reduction of azo dyes with complex structures was limited by the permeation of the dyes through the cell membrane. When the dye reduction system contained redox mediators, the quinones could transfer reduction equivalents from the periplasmically orientated parts of the respiratory chain to the azo dyes. This mechanism does not require the penetration of the azo dyes through the cell membranes and therefore explains the ability of bacteria to reduce azo dyes with complex structures.

\section{Conclusion}

In this study, strain CD-2 was used based on its ability to decolorize azo dyes. In addition, quinone compounds were used as redox mediators, and they significantly enhanced the performance of the azo dye decolorization. The results demonstrated that Lawsone was the most effective redox mediator among the quinone compounds tested. The best concentration of Lawsone added in the decolorization system was $0.1 \mathrm{mmol} / \mathrm{L}$. The strain exhibited good decolorization ability at temperatures from $20^{\circ} \mathrm{C}$ to $45^{\circ} \mathrm{C}$ and

Table 2. The effect of Lawsone on different dye decolorization.

\begin{tabular}{ccc}
\hline \multirow{2}{*}{ Dye } & \multicolumn{2}{c}{ Reduction rates (mg dye/g cell/h) } \\
\cline { 2 - 3 } & 0.21 & The strain with Lawsone \\
\hline Ponceau S & 1.44 & 6.59 \\
Eriochrome Red B & 3.84 & 2.97 \\
Gongo Red & 1.79 & 8.15 \\
Methyl Red & & 2.30 \\
\hline
\end{tabular}


$\mathrm{pH}$ values from 4 to 9 . Moreover, the strain CD-2 could also degrade Methyl Orange effectively in high salt concentrations. With Lawsone as redox mediator, the strain could decolorize various azo dyes with different chemical structures in a short time. All these results suggested that the strain CD-2 mediated by Lawsone has a great potential for dye-contaminated water treatment.

\section{Acknowledgements}

This study was supported by the National Natural Science Foundation of China (31170553) and the Fundamental Research Funds for the Central Universities (2572015BA04).

\section{References}

[1] Raffi, F., Hall, J.D. and Cerniglia, C.E. (1997) Mutagenicity of Azo Dyes Used in Foods, Drugs and Cosmetics before and after Reduction by Clostridium Species from the Human Intestinal Tract. Food and Chemical Toxicology, 35, 897-901. http://dx.doi.org/10.1016/S0278-6915(97)00060-4

[2] Stolz, A. (2001) Basic and Applied Aspects in the Microbial Degradation of Azo Dyes. Applied Microbiology and Biotechnology, 56, 69-80. http://dx.doi.org/10.1007/s002530100686

[3] Vaidya, A.A. and Datye, K.V. (1982) Environmental Pollution during Chemical Processing of Synthetic Fibres. Color Age, 14, 3-10.

[4] Deng, D.Y., Guo, J., Zeng, G.Q. and Sun, G.P. (2008) Decolorization of Anthraquinone, Triphenylmethane and Azo Dyes by a New Isolated Bacillus cereus Strain DC11. International Biodeterioration and Biodegradation, 62, 263-269. http://dx.doi.org/10.1016/j.ibiod.2008.01.017

[5] Robinson, T., Geo, McMullan, G., Marchant, R. and Nigam, P. (2001) Remediation of Dyes in Textile Effluent: A Critical Review on Current Treatment Technologies with a Proposed Alternative. Bioresource Technology, 77, 247-255. http://dx.doi.org/10.1016/S0960-8524(00)00080-8

[6] Rafii, F., Franklin, W. and Cerniglia, C.E. (1990) Azoreductase Activity of Anaerobic Bacteria Isolated from Human Intestinal Microflora. Applied Environmental Microbiology, 56, 2146-2151.

[7] Chang, J.S., Chen, B.Y. and Lin, Y.S. (2004) Stimulation of Bacteria Decolorization of an Azo Dye by Extracellular Metabolites from Escherichia coli Strain $\mathrm{NO}_{3}$. Bioresource Technology, 91, 243-248. http://dx.doi.org/10.1016/S0960-8524(03)00196-2

[8] Modi, H.A., Rajputm, G. and Ambasana, C. (2010) Decolorization of Water Soluble Azo Dyes by Bacterial Cultures, Isolated from Dye House Effluent. Bioresource Technology, 101, 6580-6583. http://dx.doi.org/10.1016/j.biortech.2010.03.067

[9] Moutaouakkil, A., Zeroual, Y., Dzayrim, F.Z., Talbi, M., Lee, K. and Blaghena, M. (2003) Purification and Partial Characterization of Azoreductase from Enterobacter agglomerans. Archives of Biochemistry and Biophysics, 413, 139-146. http://dx.doi.org/10.1016/S0003-9861(03)00096-1

[10] Hong, Y.G., Guo, J. and Sun, G.P. (2008) Characteristics and Phylogenetic Analysis of the Facultative Anaerobic Dissimilatory Azo Reducing Bacteria from Activated Sludge. International Biodeterioration and Biodegradation, 61, 313-318. http://dx.doi.org/10.1016/j.ibiod.2007.10.007 
[11] Vander, Z.F.P., Bisschops, I.A.E. and Letting, G. (2003) Activated Carbon as an Electron Acceptor and Redox Mediator during the Anaerobic Biotransformation of Azo Dyes. Environmental Science and Technology, 37, 402-408. http://dx.doi.org/10.1021/es025885o

[12] Rau, J., Knackmuss, H.J. and Stolz, A. (2002) Effects of Different Quinoid Redox Mediators on the Anaerobic Reduction of Azo Dyes by Bacteria. Environmental Science and Technology, 36, 1497-1504. http://dx.doi.org/10.1021/es010227+

[13] Kudlich, M., Keck, A., Klein, J. and Stolz, A. (1997) Localization of the Enzyme System Involved in the Anaerobic Degradation of Azo Dyes by Sphingomonas sp. BN6 and Effect of Artificial Redoxmediators on the Rate of Azo Reduction. Applied and Environmental Microbiology, 63, 3691-3694.

[14] Pearce, C.I., Christie, R., Boothman, C. von Canstein, H., Guthrie, J.T. and Lioyd, J.R. (2006) Reactive Azo Dye Reduction by Shewanella Strain J18 143. Biotechnology and Bioengineering, 95, 692-703. http://dx.doi.org/10.1002/bit.21021

[15] Dos Santos, A.B., Bisschops, I.A.E., Cervantes, F.J. and Van Lier, J.B. (2004) Effect of Different Redox Mediators during Thermophilicazo Dye Reduction by Anaerobic Granular Sludge and Comparative Study between Mesophilic $\left(30^{\circ} \mathrm{C}\right)$ and Thermophilic $\left(55^{\circ} \mathrm{C}\right)$ Treatments for Decolourisation of Textile Wastewaters. Chemosphere, 55, 1149-1157. http://dx.doi.org/10.1016/j.chemosphere.2004.01.031

Submit or recommend next manuscript to SCIRP and we will provide best service for you:

Accepting pre-submission inquiries through Email, Facebook, LinkedIn, Twitter, etc. A wide selection of journals (inclusive of 9 subjects, more than 200 journals)

Providing 24-hour high-quality service

User-friendly online submission system

Fair and swift peer-review system

Efficient typesetting and proofreading procedure

Display of the result of downloads and visits, as well as the number of cited articles Maximum dissemination of your research work

Submit your manuscript at: http://papersubmission.scirp.org/ 